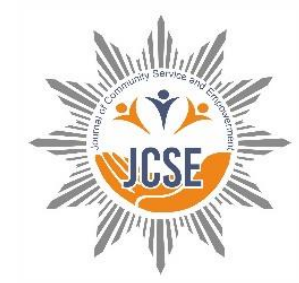

\title{
Introduction and early measurement of carbon footprint concepts to respond the challenge of SDGs-Goal 13
}

\author{
S. Santhyamia ${ }^{1, a,{ }^{*}}$, Moh. Isna Al Mubarok ${ }^{a}, V^{2}$ akha Yulia Nurzahraa \\ ${ }^{a}$ Department of Biology Education, Faculty of Teacher Training and Education, Universitas Muhammadiyah Surakarta, Jl. A. Yani, Mendungan, \\ Pabelan, Kec. Kartasura, Kabupaten Sukoharjo, Jawa Tengah 57162 \\ 1san915@ums.ac.id ${ }^{*}$ \\ * Corresponding author
}

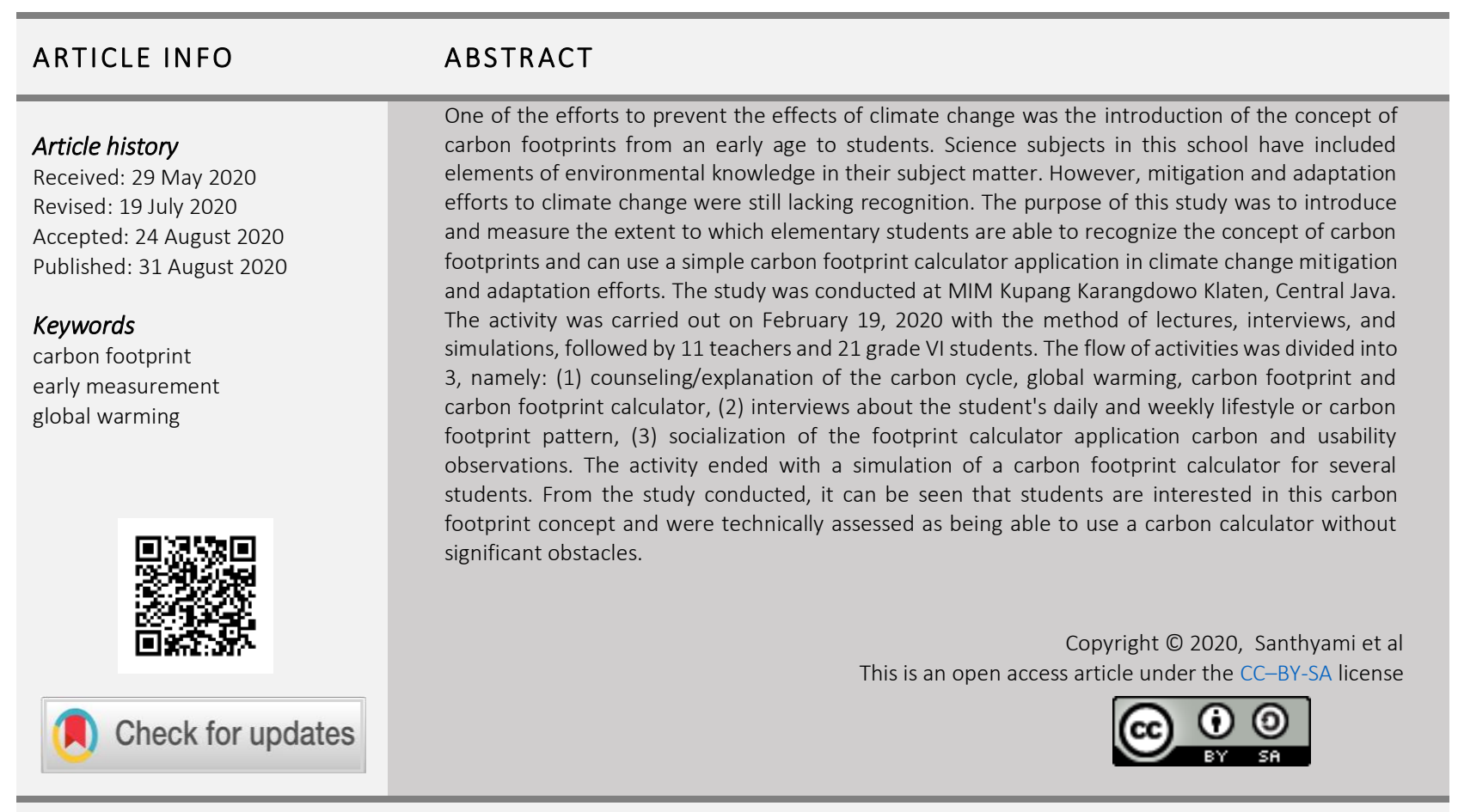

How to cite: Santhyami, S., Al Mubarok, M., \& Nurzahra, V. (2020). Introduction and early measurement of carbon footprint concepts to respond the challenge of SDGs-Goal 13. Journal of Community Service and Empowerment, 1(2), 102-107. doi:

https://doi.org/10.22219/jcse.v1i2.12322

\section{PENDAHULUAN}

Salah satu dari tujuan Pembangunan Berkelanjutan atau Sustainable Development Goals (SDGs) yang dicanangkan PBB adalah pengambilan tindakan cepat untuk mengatasi perubahan iklim dan dampaknya. Tujuan ini tertuang dalam tujuan ke 13, atau dikenal dengan Goal 13. Perubahan iklim disebabkan oleh emisi gas rumah kaca terutama gas karbondioksida $\left(\mathrm{CO}_{2}\right)$ (UN ESCAP, 2012; UNDP, 2016). Setiap kegiatan harian yang berbasis energi terutama energi fosil akan menghasilkan emisi gas jenis ini (Citraningrum, 2019; Hudha, Husamah, \& Rahardjanto, 2019; Husamah \& Rahardjanto, 2019; Prihatmaji, Fauzy, Rais, \& Firdaus, 2016; Sulistyono, 2005). Sehubungan dengan itu dikenal suatu konsep yang disebut sebagai jejak karbon atau carbon footprint yang dapat mengukur aktivitas manusia yang menimbulkan dampak terhadap lingkungan.

Jejak karbon adalah jumlah total karbondioksida yang kita pertanggungjawabkan dilepaskan ke atmosfer (IESR Indonesia, 2011). Ukuran jejak karbon adalah dalam unit $\mathrm{CO}_{2}$. Jejak karbon dapat dibedakan menjadi dua jenis, yaitu jejak karbon primer dan jejak karbon sekunder (Blonk, Kool, Luske, Ponsioen, \& Scholten, 2010; Kenny \& Gray, 2009; LoyarteLópez, Barral, \& Morla, 2020; Pandey, Agrawal, \& Pandey, 2011; Wibowo, Sholeh, \& Rizkyawan, 2020; WWF, 2020; Zhu, Zhang, Gao, \& Mei, 2020). Jejak karbon primer adalah sejumlah $\mathrm{CO}_{2}$ secara langsung dilepaskan ke udara. Contohnya adalah kegiatan memasak atau menggunakan transportasi berbahan bakar fosil (IESR Indonesia, 2020; Ismiyati, Marlita, \& Saidah, 
2014; Wulandari, Hermawan, \& Purwanto, 2013). Jejak karbon sekunder dilepaskan oleh kegiatan manusia yang dihasilkan oleh peralatan elektronik rumah yang menggunakan daya listrik. Warga dunia semakin bertambah, maka kebutuhan terhadap daya listrik juga terus meningkat. Abad milenium ini ditandai dengan hampir semua kebutuhan energi manusia didapat dari mengubah sumber energi fosil. Jejak karbon sekunder walaupun tidak langsung menggunakan energi fosil, namun sebagian besar pembangkit listrik utama di bumi ini masih menggunakan energi fosil sebagai sumber energinya (Wiedmann \& Barrett, 2010), yang tentunya juga akan memberikan efek signifikan.

Estimasi besaran jejak karbon dianggap sama dengan GWP 100 (100 years Global Warming Potential). Definisi perhitungan jejak karbon adalah suatu pendekatan untuk mengestimasi berapa besar karbon yang dihasilkan oleh suatu sistem. Estimasi dapat dilakukan baik untuk individu ataupun kelompok (komunal). Estimasi jejak karbon dapat dilakukan dengan perhitungan jumlah energi listrik yang digunakannya; kegiatan transportasi yang dipilih; banyak minyak bahan bakar yang digunakan; apakah individu tersebut melakukan usaha daur ulang atau tidak; usaha penanaman pohon yang dilakukan; dll. Adanya pengetahuan tentang besarnya jejak karbon dan dampak perubahan lingkungan akan menimbulkan kesadaran dari tiap-tiap pihak untuk terus mengurangi jejak karbon yang dihasilkan oleh individu maupun kelompok (Wright, Kemp, \& Williams, 2011).

Beberapa tahun belakangan ini berbagai organisasi berbasis lingkungan, lembaga pemerintah ataupun non pemerintah, bahkan pribadi sudah banyak mengembangkan kalkulator jejak karbon berbasis online. Mulai dari yang sifatnya begitu akurat sampai kalkulator sederhana yang bisa dioperasikan dengan mudah oleh siswa. Salah satu kalkulator karbon berbasis online dengan bahasa online yang mudah diakses oleh berbagai kalangan termasuk siswa adalah http://carboncalculator.iesr.or.id/. Kalkulator online ini dikembangkan oleh Institute for Essential Services Reform (IESR). Estimasi jejak karbon disesuaikan dengan kondisi dan situasi pola konsumsi energi dan gaya hidup masyarakat Indonesia, dengan faktor emisi yang sesuai dengan profil pasokan energi di Indonesia.

Dalam rangka mengurangi pemanasan global, akan sangat efektif jika upaya edukasi terhadap konsep jejak karbon diterapkan sedini mungkin. Informasi terkait berbagai metode penghitungan jejak karbon harian dan tahunan, upaya-upaya pengurangan jejak karbon dan komiten dirasa perlu untuk disosialisasikan dan dipadukan dalam materi pengayaan sekolah. Oleh karena itu studi ini bertujuan untuk mengenalkan dan mengukur sejauh mana siswa SD mampu mengenal konsep jejak karbon dan dapat menggunakan aplikasi kalkukator jejak karbon sederhana dalam upaya mitigasi dan adaptasi perubahan iklim. Studi ini dilaksanakan di MIM Kupang Karangdowo Klaten Jawa Tengah.

Mata pelajaran IPA di MIM Kupang Karangdowo Klaten Jawa Tengah sudah memasukkan unsur pengetahuan lingkungan dalam materi pelajarannya sebagai bentuk usaha pengenalan pentingnya menjaga lingkungan dari dini. Namun demikian, bentuk nyata yang dapat diterapkan dalam kehidupan sehari-hari terutama dalam usaha mitigasi dan adaptasi perubahan iklim masih minim contoh. Untuk memberikan gambaran umum mengenai bentuk kontribusi siswa perlu diajak secara langsung menghitung produksi karbon yang dihasilkan oleh individu sehari-hari. Untuk memberikan dasar pengetahuan mengenai siklus karbon, jejak karbon dan cara menggunakan aplikasi kalkukator jejak karbon maka perlu dilakukan pengenalan tentang cara penghitungan jejak karbon sederhana yang dapat dengan mudah diaplikasikan oleh siswa SD. Solusi yang diberikan untuk mengatasi permasalahan yang terjadi di MIM Kupang Karangdowo Klaten Jawa Tengah adalah mengadakan pengenalan dan sosialisasi tentang cara penghitungan jejak karbon sederhana yang dapat dengan mudah diaplikasikan oleh siswa SD. Tujuan dari kegiatan ini adalah untuk memperkenalkan dan mengukur sejauh mana siswa SD mampu mengenal konsep jejak karbon dan dapat menggunakan aplikasi kalkulator jejak karbon sederhana dalam upaya mitigasi dan adaptasi perubahan iklim.

\section{METODE}

Studi dilaksanakan di MIM Kupang Karangdowo Klaten Jawa Tengah pada bulan Februari 2020. Kegiatan dilaksanakan oleh tim yang terdiri dari satu orang dosen sebagai pemateri, dan 2 orang mahasiswa. Mahasiswa bertugas sebagai asisten yang membantu peserta yang mengalami kesulitan teknis dalam menggunakan aplikasi kalkulator selama kegiatan berlangsung. Kegiatan ini diikuti oleh 11 orang guru dan 21 orang siswa kelas VI. Siswa kelas VI dipilih didampingi guru karena materi yang disampaikan cukup kompleks.

Studi dilaksanakan dalam dua tahap yaitu pengenalan tentang siklus karbon dan kaitannya dengan pemanasan global serta jejak karbon dan pengecekan jejak karbon siswa dengan menggunakan aplikasi kalkulator karbon. Alur kegiatan dibagi menjadi 3 yaitu: (1) Penyuluhan/penjelasan mengenai siklus karbon, pemanasan global, jejak karbon serta kalkulator jejak karbon, (2) wawancara mengenai gaya hidup atau pola jejak karbon harian dan mingguan siswa, (3) sosialisasi dan pengecekan tingkatan jejak karbon siswa menggunakan aplikasi kalkulator karbon. Aplikasi kalkulator karbon dapat diakses secara gratis pada situs http://carboncalculator.iesr.or.id/.

\section{HASIL DAN PEMBAHASAN}

Kegiatan ini diawali dengan sosialisasi perubahan iklim secara lisan. Siswa diajak untuk membedakan antara konsep cuaca dan iklim sebagai upaya untuk menggiring pendapat siswa mengenai perubahan iklim. Pada penyampaian awal ditampilkan gambar-gambar ekosistem dan populasi (seperti ekosistem pegunungan, ekosistem terumbu karang, populasi beruang kutup dan lain-lain) di bumi sebelum dan sesudah terjadi kerusakan yang diakibatkan karena perubahan iklim. Gambar-gambar ini dipilih dan ditampilkan untuk mendekati simpati siswa secara emosional. 
Dalam pemaparan mengenai perubahan iklim, pemateri menyisipkan data-data mengenai perubahan iklim terbaru dan hubungannya dengan deforestasi. Perubahan iklim akibat emisi gas rumah kaca terutama karbondioksida merupakan permasalahan serius yang dihadapi dunia saat ini. Emisi sebagian besar berasal dari kegiatan pembakaran sumber energi fosil dan perubahan fungsi lahan terutama deforestasi dan degradasi hutan tropis (Panjiwibowo, Soejachmoen, Tanujaya, \& Rusmantoro, 2003). Hutan hujan tropis di Asia Tenggara telah berkurang sekitar 158 ribu km² dalam selang waktu 2000 - 2012 (Hansen et al., 2013). Sampai tahun 2014, Indonesia merupakan negara penyumbang emisi tertinggi ketiga di dunia (Margono, Potapov, Turubanova, Stolle, \& Hansen, 2014). Data terbaru IPCC menunjukkan bahwa suhu rata-rata permukaan bumi secara global [global mean surface temperature (GMST)] pada decade $2006-2015$ adalah $0.87^{\circ} \mathrm{C}$ (berkisar antara $0.75^{\circ} \mathrm{C}$ dan $0.99^{\circ} \mathrm{C}$ ) lebih tinggi dibandingkan rata-rata pada periode $1850-1900$. Pemanasan global dari kegiatan antropogenik saat ini meningkat sebesar $0.2^{\circ} \mathrm{C}$ per decade akibat emisi masa lalu dan yang sedang berlangsung. Pemanasan global diperkirakan akan mencapai $1.5^{\circ} \mathrm{C}$ antara tahun 2020 dan 2052 jika terus meningkat pada kecepatan sekarang (IPCC, 2018).

Selain menampilkan perubahan ekosistem, pengenalan mengenai konsep perubahan iklim juga diberikan dengan pendekatan kerugian secara ekonomi bagi siswa itu sendiri, seperti pendekatan dari mitigasi perubahan iklim terhadap pola pertanian, dimana rata-rata orangtua dari siswa berprofesi sebagai petani. Peserta siswa sangat antusias dengan konsep dampak perubahan iklim, ditandai dengan banyaknya pertanyaan dari peserta. Setelah pengenalan konsep akibat perubahan iklim, selanjutnya dilakukan sosialisasi mengenai siklus karbon di dalam ekosistem dan bagaimana galat dalam siklus ini kemudian menggiring kepada perubahan global berupa pemanasan suhu bumi. Pengenalan konsep ini disampaikan dengan contoh video.

Sebelum masuk ke dalam sesi pengenalan konsep aplikasi kalkulator karbon, dilakukan wawancara open ended interview mengenai pola gaya hidup atau pola jejak karbon harian dan mingguan kepada siswa dipandu oleh guru. Setelah tanya jawab dan sesi wawancara selesai, selanjutnya adalah pengenalan aplikasi kalkulator karbon dan praktek penggunaannya dicontohkan kepada satu orang volunteer siswa. Aplikasi kalkulator karbon dapat diakses secara gratis pada situs http://carboncalculator.iesr.or.id/ yang ditunjukkan pada Gambar 1.

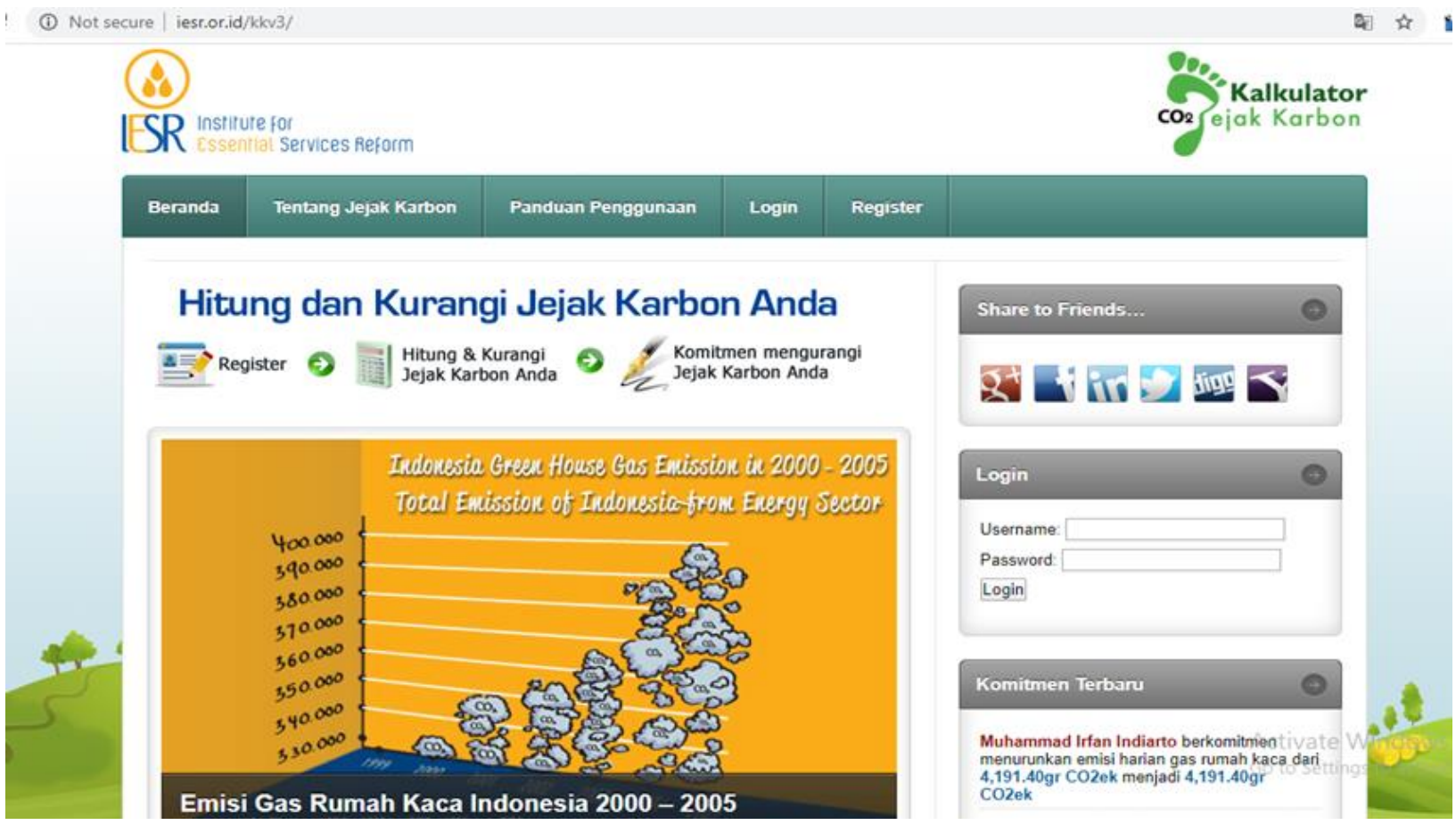

Gambar 1. Tampilan salah satu website kalkulator karbon

Pada Gambar 2, Volunteer siswa yang bersedia untuk ke depan kelas memperagakan cara penggunaan kalkulator bernama Farhad dan didampingi oleh satu orang guru. Siswa lain memperhatikan dan sembari bertanya terkait teknis penggunaan. Siswa lain bisa mencatat cara kerja kalkulator karbon dan ditugaskan untuk mencoba sendiri di rumah dengan perangkat handphone atau laptop masing-masing karena peraturan sekolah bahwa siswa dilarang membawa HP. Beberapa peserta guru langsung mencoba aplikasi kalkulator dengan handphone masing-masing. 


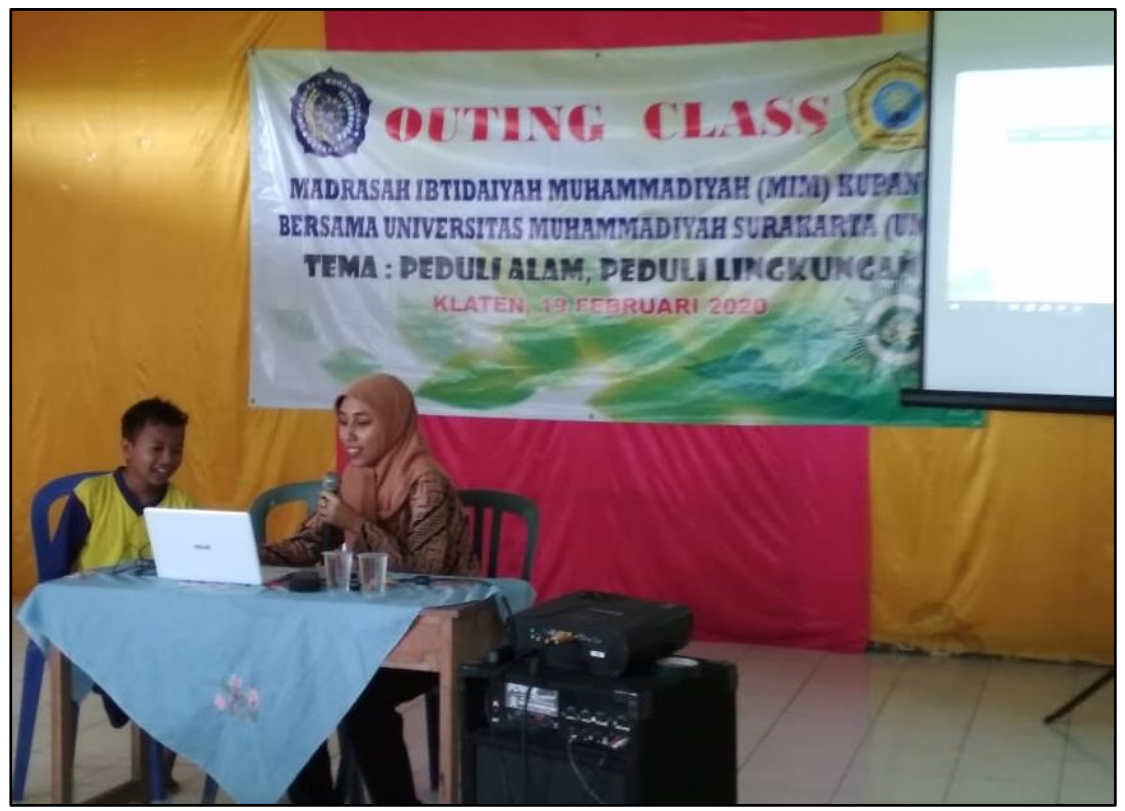

Gambar 2. Kegiatan pengenalan kalkulator karbon

Langkah pertama adalah log in dan register ke dalam website. Untuk log in dan register dibutuhkan email. Semua siswa dan guru yang mengikuti simulasi ini terdata sudah memiliki email. Setelah melakukan registrasi dan mengisi data pribadi, maka peserta dapat langsung menggunakan kalkulator dengan panduan-panduan yang sudah cukup jelas disediakan dalam website ini. Ketika dipraktekkan di depan kelas, semua siswa dapat mengikuti dengan baik.

Dua faktor penting yang diperhatikan dalam menghitung jejak karbon adalah jenis kegiatan yang dilakukan dan faktor emisinya. Jenis kegiatan yang dilakukan seperti halnya jenis barang yang digunakan, jenis makanan yang dimakan, jenis bahan bakar yang dikonsumsi dan perilaku terhadap barang-barang itu. Misalnya, bepergian dengan transportasi publik akan lebih kecil jejak karbonnya daripada dengan kendaraan pribadi (dengan jarak yang sama) atau menggunakan lampu pijar lebih besar jejak karbonnya daripada lampu LED.

Dengan banyaknya jenis sumber karbon ini, maka kalkulator karbon IESR telah mengkategorikan enam jenis sumber karbon harian individu. Enam sumber karbon tersebut adalah penerangan, peralatan dapur, peralatan rumah tangga, peralatan pribadi, hiburan dan informasi dan komunikasi. Untuk setiap sumber karbon kemudian diperinci untuk setiap kategorinya. Contohnya untuk penerangan, kepada pengguna akan ditampilkan beberapa pilihan jenis lampu yang digunakan yaitu misalnya lampu pijar, Neon - CFL, atau LED. Pada awalnya siswa kurang memahami jenis-jenis lampu yang mereka gunakan di rumah. Namun setelah ditampilkan gambarnya di slide presentasi, mereka bisa mengira-ngira jenis lampu yang digunakan. Untuk setiap jenis lampu kemudian ada opsi besar daya dan lama penggunaan. Siswa ditugaskan untuk menanyakan besarnya daya lampu yang mereka gunakan secara pribadi.

Pada sesi simulasi, sumber karbon terbesar sampel siswa berasal dari kategori peralatan rumah tangga yaitu misalnya seperti kulkas, mesin cuci, setrika, dispenser dll sementara yang terkecil adalah kategori transportasi karena umumnya siswa di MIM Kupang Karangduwo menggunakan sepeda untuk pergi ke sekolah dan berpergian lainnya. Sebagai perbandingan, masyarakat kantoran perkotaan justru memiliki jejak karbon tertinggi berasal dari sektor transportasi dengan rata-rata 2,3 $\pm 0,78$ ton $\mathrm{CO}_{2}^{-\mathrm{e}} /$ orang/ tahun. Tidak mengherankan karena tingkat mobilisasi orang perkotaan lebih tinggi dibandingkan masyarakat pedesaan (Santoso, 2017). Dari hasil simulasi, siswa volunteer mendapatkan hasil akhir jejak karbon totalnya adalah 0.95 ton $\mathrm{CO}^{-\mathrm{e}}$ per tahun. Angka ini jauh lebih kecil dibandingkan jejak karbon rata-rata penduduk Indonesia yaitu 1.7 ton CO2-e per tahun (The World Bank, 2016). Dengan hasil ini maka siswa dapat membandingkan jejak karbonnya dengan siswa yang lain.

Setelah sesi pengenalan dan simulasi penggunaan kalkulator karbon, maka kegiatan studi diakhiri dengan sesi pengukuran komitmen pengurangan jejak karbon individu siswa. Kemajuan komitmen ini pun dapat dicatat oleh siswa dalam aplikasi dan di update per tahun untuk melihat perkembangan komitmen dan seberapa besar mereka dapat mengurangi submisi karbonnya pada tahun tersebut. Dalam sesi ini siswa diberikan pengetahuan mengenai cara-cara untuk bisa berkomitmen dalam mengurangi dan menghapus jejak karbon. Pengurangan jejak karbon secara sederhana dapat dilakukan mandiri oleh siswa seperti halnya dengan usaha-usaha berikut; menggunakan lampu secara bijak, mengurangi penggunaan AC, pengering pakaian, hair drier dan lain-lain secara berlebihan, mengurangi sampah anorganik dan mengurangi konsumsi daging merah. Menurut Dahlan (2007), usaha penghapusan jejak karbon adalah dengan cara menanam pohon dan daur ulang sampah. Siswa diberi stimulasi bahwa hanya dengan menanam satu pohon saja per tahun maka siswa dapat membayar 'hutang' total karbonnya kepada bumi pada tahun itu. Sebagai contoh, satu pohon trembesi bisa menyerap 28 ton $\mathrm{CO}_{2}$ per tahun atau pohon nangka mampu menyerap $126 \mathrm{~kg} \mathrm{CO} 2$ per tahun 


\section{KESIMPULAN}

Kegiatan mengenalkan dan mengukur sejauh mana siswa SD mampu mengenal konsep jejak karbon dan dapat menggunakan aplikasi kalkukator jejak karbon sederhana dalam upaya mitigasi dan adaptasi perubahan iklim di MIM Karangduwo Kupang Klaten secara umum berjalan secara baik dan lancar. Upaya pengenalan konsep siklus karbon dan pemanasan global cukup menarik perhatian peserta dan diiringi dengan diskusi lepas terutama pada pendalaman dampak perubahan pola iklim pada bumi. Dari proses wawancara lepas, dapat digali informasi mengenai pola gaya hidup atau pola jejak karbon harian dan mingguan siswa dipandu oleh guru. Informasi ini kemudian digunakan sebagai dasar untuk melakukan sesi simulasi kalkulator karbon. Dalam sesi terakhir yaitu simulasi aplikasi kalkulator karbon, secara umum tidak terdapat kesulitan bagi guru dan siswa dalam mengoperasikan aplikasi. Kendala dari kegiatan ini adalah kalkulator karbon yang dikenalkan adalah kalkulator berbasis internet. Sebagian besar siswa masih kesulitan mendapatkan dan menggunakan akses internet di rumah mereka. Pada umumnya peserta baik siswa ataupun guru sangat tertarik dengan materi yang disampaikan karena merupakan materi yang berhubungan dengan pelajaran IPA dan dapat diterapkan langsung dalam kehidupan sehari-hari.

\section{UCAPAN TERIMA KASIH}

Ucapan terimakasih diberikan kepada Universitas Muhammadiyah Surakarta yang mendanai kegiatan pengabdian masyarakat ini, seluruh staf guru dan siswa MIM Karangduwo, Kupang Klaten, dan rekan Lina Agustina, M.Pd., atas bantuan teknis pada saat kegiatan pengabdian.

\section{REFERENSI}

Blonk, H., Kool, A., Luske, B., Ponsioen, T., \& Scholten, J. (2010). Methodology for assessing carbon footprints of horticultural products horticultural products. CA Gouda: Blonk Milieu Advies BV.

Citraningrum, M. (2019). Energi kita. Jakarta: Institute for Essential Service Reform.

Dahlan, E. N. (2007). Analisis kebutuhan luasan hutan kota sebagai sink gas CO2 antropogenik dari bahan bakar minyak dan gas (Program Studi Ilmu Pengetahuan Kehutanan, IPB). Retrieved from https://repository.ipb.ac.id/handle/123456789/40542

Hansen, M. C., Potapov, P. V., Moore, R., Hancher, M., Turubanova, S. A., Tyukavina, A., ... Townshend, J. R. G. (2013). High-resolution global maps of 21st-century forest cover change. Science, 342(6160), 850-853. https://doi.org/10.1126/science.1244693

Hudha, A. M., Husamah, H., \& Rahardjanto, A. (2019). Etika Lingkungan (Teori dan praktik pembelajarannya). Malang, Indonesia: UMM Press.

Husamah, H., \& Rahardjanto, A. (2019). Bioindikator (Teori dan aplikasi dalam biomonitoring). Malang: UMM Press.

IESR Indonesia. (2011). Potensi penurunan emisi Indonesia melalui perubahan gaya hidup individu. Jakarta.

IESR Indonesia. (2020). Jejak karbon (Carbon footprint). Retrieved April 14, 2020, from IESR Indonesia website: http://www.iesr.or.id/kkv3/tentang-jejak-karbon/

IPCC. (2018). Global warming of $1.5^{\circ} \mathrm{C}$ An IPCC Special Report on the impacts of global warming of $1.5^{\circ} \mathrm{C}$ above preindustrial levels and related global greenhouse gas emission pathways, in the context of strengthening the global response to the threat of climate change, (V. Masson-Delmotte, P. Zhai, H.-O. Pörtner, D. Roberts, J. Skea, P. R. Shukla, ... T. Waterfield, Eds.). Intergovernmental Panel on Climate Change.

Ismiyati, Marlita, D., \& Saidah, D. (2014). Pencemaran udara akibat emisi gas buang kendaraan bermotor. Jurnal Manajemen Transportasi \& Logistik (JMTransLog), 1(3), 241-248. Retrieved from https://media.neliti.com/media/publications/112707-ID-pencemaran-udara-akibat-emisi-gas-buang.pdf

Kenny, T., \& Gray, N. F. (2009). A preliminary survey of household and personal carbon dioxide emissions in Ireland. Environment International, 35(2), 259-272. https://doi.org/10.1016/j.envint.2008.06.008

Loyarte-López, E., Barral, M., \& Morla, J. C. (2020). Methodology for carbon footprint calculation towards sustainable innovation in intangible assets. Sustainability (Switzerland), 12(4), 1-14. https://doi.org/10.3390/su12041629

Margono, B. A., Potapov, P. V., Turubanova, S., Stolle, F., \& Hansen, M. C. (2014). Primary forest cover loss in indonesia over 2000-2012. Nature Climate Change, 4(8), 730-735. https://doi.org/10.1038/nclimate2277

Pandey, D., Agrawal, M., \& Pandey, J. S. (2011). Carbon footprint: Current methods of estimation. Environmental Monitoring and Assessment, 178(1-4), 135-160. https://doi.org/10.1007/s10661-010-1678-y

Panjiwibowo, C., Soejachmoen, M. H., Tanujaya, O., \& Rusmantoro, W. (2003). Mencari pohon uang: CDM kehutanan di Indonesia. Jakarta: Pelangi.

Prihatmaji, Y. P., Fauzy, A., Rais, S., \& Firdaus, F. (2016). Analisis carbon footprint gedung perpustakaan pusat, sebagai preduksi emisi gas rumah kaca. AJIE - Asian Journal of Innovation and Entrepreneurship (e-ISSN:, 1(2), 148-155. Retrieved from https://journal.uii.ac.id/ajie/article/view/6372

Santoso, A. D. (2017). Jejak karbon individu pegawai di instansi pemerintah. Jurnal Teknologi Lingkungan, 18(2), 233240. Retrieved from http://ejurnal.bppt.go.id/index.php/JTL/article/download/2242/1885 
Sulistyono, S. (2005). Pemanasan global (Global Warming) dan hubungannya dengan penggunaan bahan bakar fosil. Forum Teknologi, 2(2), 47-56. Retrieved from http://ejurnal.ppsdmmigas.esdm.go.id/sp/index.php/swarapatra/article/view/60/49

The World Bank. (2016). CO2 emissions (metric tons per capita). Retrieved April 14, 2020, from Carbon Dioxide Information Analysis Center, Environmental Sciences Division, Oak Ridge National Laboratory, Tennessee, United States website: https://data.worldbank.org/indicator/EN.ATM.CO2E.PC

UN ESCAP. (2012). Statistical yearbook for Asia and the Pacific 2015. In Sustainable Development Goal 13. UN ESCAP.

UNDP. (2016). UNDP support to the implementation of sustainable development goal 13: Taking urgent action to combat climate change and its impacts. https://doi.org/10.4324/9781351067478-8

Wibowo, M. A., Sholeh, M. N., \& Rizkyawan, A. W. (2020). Lean construction: Evaluation of waste and carbon footprint in construction project. IOP Conference Series: Earth and Environmental Science, 448(1), 012057. https://doi.org/10.1088/1755-1315/448/1/012057

Wiedmann, T., \& Barrett, J. (2010). A review of the ecological footprint indicator-perceptions and methods. Sustainability, 2(6), 1645-1693. https://doi.org/10.3390/su2061645

Wright, L. A., Kemp, S., \& Williams, I. (2011). "Carbon footprinting": Towards a universally accepted definition. Carbon Management, 2(1), 61-72. https://doi.org/10.4155/cmt.10.39

Wulandari, M. T., Hermawan, \& Purwanto. (2013). Kajian emisi Co2 berdasarkan penggunaan energi rumah tangga sebagai penyebab pemanasan global (Studi kasus Perumahan Sebantengan, Gedang Asri, Susukan RW 07 Kab. Semarang). Prosiding Seminar Nasional Pengelolaan Sumberdaya Alam Dan Lingkungan 2013, 434-440. Retrieved from https://core.ac.uk/download/pdf/18605659.pdf

WWF. (2020). Carbon footprint: Exploring the UK's contribution to climate change. Retrieved from https://www.wwf.org.uk/sites/default/files/2020-04/FINAL-WWFUK_Carbon_Footprint_Analysis_Report_March_2020\%28003\%29.pdf

Zhu, X., Zhang, T., Gao, W., \& Mei, D. (2020). Analysis on spatial pattern and driving factors of carbon emission in urbanrural fringe mixed-use communities: Cases study in East Asia. Sustainability (Switzerland), 12(8), 1-16. https://doi.org/10.3390/SU12083101 